\title{
Entrepreneurship and Local Sustainability: Is There any Relation? A Case Study in the Region Vale do Sousa
}

\author{
Nelson Duarte ${ }^{1}$
}

\begin{abstract}
:
Is there a relation between entrepreneurship/intrapreneurship and local sustainability? The studied region (Vale do Sousa North of Portugal) presents very low levels of entrepreneurship but the results for local sustainability are very interesting. Results are based on a questionnaire presented to 251 firms. Most firms (59\%) present a low level of entrepreneurship, the same percentage present a good level of sustainability and $37 \%$ a very good level. This means that firms might be more concerned with local sustainability than firm sustainability. On entrepreneurships analyses proactively got an average result of 3,49, innovation 1,27 and risk propensity 1,06, (1 to 5 linker scale). These results lead to an inexistent relation between entrepreneurship and local sustainability.
\end{abstract}

Key Words:

Entrepreneurship, Sustainability

JEL Classification: H72, L26, Q01

${ }^{1}$ School of Management and Technology of Felgueiras, e-mail: nduarte@estgf.ipp.pt 


\section{Introduction}

The concept of entrepreneurship is widely used from firm management to policy making, or even in current conversation. It is also a key word on the concept of development, because is through entrepreneurial actions that economy growth is fostered adding value and creating better social conditions to the community. Entrepreneurship is frequently associated to local development since this development can only be achieved if the organization of a group of factors will allow obtaining synergies from that organization. One of these factors is entrepreneurship, not only at a firm creation level, but essentially on firms' management and/or innovative, creative and cooperative capacities.

According to Brower (2002) there are three main references on entrepreneurship literature: Max Weber, Joseph Schumpeter and Frank Knight. These authors associated entrepreneurship to growth, but also to the concepts of innovation and risk. With an increasing research on this field some other concepts can be linked to the concept of entrepreneurship. According to Global Entrepreneurship Monitoring (GEM) on 2008 report (GEM, 2008) entrepreneurship degree must be evaluated considering the country economic development stage and the entrepreneurial attitudes, activity and aspirations. However these three factors are connected through a complex network of causes and consequences where small changes can affect in a positive or negative way the degree of entrepreneurship. This network means that entrepreneurship is not an equilibrium phenomenon. Moreover, considering all the concepts presented on Table 1 it is easy to conclude that would not be an easy task to find equilibrium among all those concepts on real situation.

Entrepreneurship can be measured by using three factors initially presented by Miller (1983): (1) Proactivity (2) Innovation and (3) Risk propensity. Lumpkin \& Dess (1996) presented a model that is frequently quoted where they bring two new factors (4) Autonomy and (5) Competitive aggressiveness; however on a later study (Lumpkin \& Dess, 2001) they found a negative relation between these two last factors.

In order to achieve the real entrepreneurship stage it is necessary on firm creation, but also the same innovative capacity on firms' management. This capacity can be achieved through a strategy, a culture and a group relation that will allow obtain competitive advantages. The concept of entrepreneurship inside the firm is usually presented as intrapreneurship. To this concept some others are associated such as social networks, useful information, and type of opportunity or personal characteristics (Ardichvili, Cardozo, \& Ray, 2003). According to Bruyat \& Julien (2000), innovation on strategic management is a concept very close to entrepreneurship. Antoncic \& Hisrich (2001) present innovation as a dimension of 
intrapreneurship, but one can go further and argue that innovation on strategic management is intrapreneurship.

Considering entrepreneurship as a style of management, Stewart, Watson, Carland, \& Carland (1998) studied the differences among entrepreneurs, small business owners and large firm managers. The results classify the entrepreneur as someone motivated, searching for success with risk propensity behavior. They promote innovation by changing products, markets or industries. Taking into consideration the quoted study and some other literatures it is possible to present some factors that distinguish these three types of managers.

Table 1: Authors and Concepts with Connections to Entrepreneurship

\begin{tabular}{|c|c|}
\hline Autor & Conceitos Associados ao termo Empreendedorismo \\
\hline Cantillon (1755); Jean Baptist Say & $\begin{array}{l}\text { Someone willing to bear financial and personal risks } \\
\text { New firm creation and management }\end{array}$ \\
\hline Knight (1921), Newman (2007) & Risk and uncertainity \\
\hline $\begin{array}{l}\text { Schumpeter (1934), Hayton \& } \\
\text { Kelly (2006); Avlonitis \& } \\
\text { Salavou (2007); Zampetakis \& } \\
\text { Moustakis (2006) }\end{array}$ & $\begin{array}{l}\text { New products, processes or supply that bring imbalances } \\
\text { to the market }\end{array}$ \\
\hline Gartner (1988) & New organizations \\
\hline Stearns \& Hills (1996) & $\begin{array}{l}\text { Economical environment, entrepreneurial and innovative } \\
\text { behaviour, organization, innovation, risk, resource } \\
\text { gathering, value added for the individual or society }\end{array}$ \\
\hline Lumpkin \& Dess (1996) & New markets and new products \\
\hline $\begin{array}{c}\text { Scott, Fadahunsi, \& } \\
\text { Kodithuwakku (1997) }\end{array}$ & Creative process of taking out economic and social value \\
\hline Hamel \& Prahalad (1997) & $\begin{array}{l}\text { Strategic architecture where intentions become reality } \\
\text { Creativity on the leverage of scarce resources will help a } \\
\text { firm to minimize the risks of pioneering }\end{array}$ \\
\hline Chagas (1999) & Key strategy for a firm success \\
\hline Stiglitz \& Driffill (2000) & New business, new products, new processes \\
\hline $\begin{array}{l}\text { Bruyat \& Julien (2000), } \\
\text { Thornberry (2001) }\end{array}$ & New ideas, job creation and economic value creation \\
\hline Kyrö (2000) & Intrapreneurship, collective behaviour of a firm \\
\hline $\begin{array}{l}\text { Kirzner (1973), Drucker (1985), } \\
\text { Eckhardt \& Shane (2003), } \\
\text { Venkataraman (1997) } \\
\end{array}$ & $\begin{array}{l}\text { Process of recognizing and exploitation of new markets, } \\
\text { products or services }\end{array}$ \\
\hline Hubler, Zaghni, \& Mussi (2003) & $\begin{array}{l}\text { Opportunity recognizing on an unstable environment in } \\
\text { order to conceive something new or to produce on a more } \\
\text { effective way }\end{array}$ \\
\hline CCE (2003) & $\begin{array}{l}\text { Opportunity identification and goal achievements by using } \\
\text { creativity and a rigorous management }\end{array}$ \\
\hline Stevenson (n.d.) & Opportunity search beyond own resources \\
\hline Acs \& Catherine (2004), Kyrö & People behaviour \\
\hline
\end{tabular}


N. Duarte

\begin{tabular}{|c|c|}
\hline$(2000)$ & \\
\hline Bratnicki (2005) & Multidisciplinary and multidimensional concept \\
\hline $\begin{array}{c}\text { White, Thornhill, \& Hampson } \\
(2007)\end{array}$ & Familiar context \\
\hline
\end{tabular}

Source: Own elaboration

Table 2: Managers' Behaviour on Different Business Units

\begin{tabular}{|c|c|c|c|}
\hline Factors & Entrepreneurs & $\begin{array}{c}\text { Small business } \\
\text { owners }\end{array}$ & Large firm managers \\
\hline Proactivity & +++ & ++ & + \\
\hline Innovation & +++ & ++ & + \\
\hline Risk propensity & +++ & + & + \\
\hline Motivation & +++ & + & + \\
\hline $\begin{array}{c}\text { Results search } \\
\text { Management }\end{array}$ & +++ & ++ & +++ \\
\hline
\end{tabular}

Source: Own elaboration

Table 2 presents a summary of some characteristics related to entrepreneurship but also present on other management styles. The result allows concluding that there are not specific characteristics exclusive to entrepreneurship since all of them are present in different management styles. The combination of some of those factors together with economic environment, local facilities, or even local culture will define the contribution that each firm will give for local development and sustainability.

According to the report "SMEs: Local Strength, Global Reach" (OECD, 2000) small businesses play the main role on economic growth and represent the largest percentage of employment. More than $95 \%$ of firms in OECD countries are small or micro and they account for $60 \%$ to $70 \%$ of total employment. Micro firms are the largest percentage in European Union (93\%) and as defended by Shanklin \& Ryans (1998), these firms should be taken into consideration by governments when it comes to economic stimulus.

$\mathrm{Hu}$ (2003) begins his study by saying: "The well-known futurist, John Naisbit long predicted the growing importance of the concept: 'small is beautiful'. Acs as an economist observes small business in the US and Europe and finds an increasing trend in their importance since the nineteen-eighties. Liargovas suggests that small firms are considered the 'back-bone' of local economies in Europe. In the Asian 
financial crisis, small and medium scaled enterprises were depicted as 'an army of ants' for Taiwan to fight the crisis. As Acs, Carlsson and Karlsson put it: As we move toward the $21^{\text {st }}$ century, the emerging conventional wisdom seems to suggest that small firms and entrepreneurship are both necessary for long-run macroeconomic prosperity". This means that besides the important role that small firms play on social level they are also important on what concerns long run prosperity.

Abouzeedan \& Busler (2004) present SMEs performance as an essential factor for economic development of any country. They argue that SMEs are the seed for large firms. Quoting Castrogiovani (1996) and Monk (2000) they defend that most bankruptcy in small firms occurs on the first five years, but if a large percentage of small firms were able to grow there would be a very positive impact on global economy. This idea is in accordance with the studies of Wright \& Etemad (2001) and $\mathrm{Hu}(2003)$.

Eversole (2003) argues that all over the world governments and development agencies have been pointing small businesses as a development tool since this type of firms are one of the most sustainable ways for local economic growth, employment creation and poverty reduction. However as Pissarides (1999) argues, because of their dimension these firms can easily find obstacles and restrictions, higher transaction costs and even a limited management. But if they have some disadvantages, their dimension can also be pointed as an important factor for their success, since they are more flexible. According to Inforegio (2000) through their flexibility and job creation potential small firms can play an important role on regional development. Caloghirou, Protogerou, Spanos, \& Papagiannakis (2004) argue that SMEs are more flexible and faster than large firms when it is necessary to adapt to new market conditions. So, one can say that small firms have the potential to be more innovative on their management than large ones.

United Nations [UN (1997); Wolfenshon (1998)] defend that various tools have been used as an answer to poverty reduction among the poor that live with less than a US Dollar a day (more than 1,2 million people [PNUD (2003)]) and among those tools micro firms have been seen as a way to offer financial assistance to help the poorest and breaking out the poverty cycle.

Some other authors (Hewitt, 2000 in Beaver, 2002) present small businesses as a priority on governmental efforts to promote innovation and increase firm productivity. Storey (1994) in Beaver (2002) presents small firms as a vital ingredient for the establishment of a modern and vibrant economy. The same author argues that on the past 30 years small firms have been playing one of the most sustainable programs on economic welfare and countries prosperity. 
These firms present a strong relation with entrepreneurship because like the entrepreneurs they need to adapt and act proactively to the market in order to survive on the long term] (Kim Knotts \& Jones, 2008), which is possible through the establishment of networks (Arend, 2006; Acquaah, 2007). At the same time they play an important role at social level (Baptista \& Carias, 2007) as well as on local sustainable development (Vargas, 2000; Palacio, 2006).

Craig, Jackson, \& Thomson (2005), argue that small firms work as an incubator for growth being the place where innovation occurs and new business ideas become viable businesses. On what concerns growth, OECD (2003) presents three key factors: (1) Physical capital accumulation, (2) Human capital accumulation and (3) R\&D. It is interesting to notice that all of them are related to firms.

Small firms are important for economic development but also for sustainable development. According to CE (2002) 50\% of SMEs are supporting external social activities, which mean that besides their role on job creation and economic development they also have a role to play on social and environmental areas. However most of these activities present an occasional character and are not a part of firm strategy.

Many authors assume an important role of small firms on local development (Stel, Carree, \& Thurik, 2005); Lawrence, Collins, Pavlovich, \& Arunachalam, 2006; Duarte, 2007), or even the advantages that firms can get on risk reduction by adopting sustainability measures (Silva \& Quelhas, 2006), some others argue that these firms have no motivation to take this type of actions (Revell \& Blackburn, 2007). Even without a consensual theory about the role of firms on sustainability some alternative management models have been suggested aiming sustainability (Kerr, 2006;, Rocha, Searcy, \& Karapetrovic, 2007; Espinosa, Harnden, \& Walker, 2008), that can be obtained through entrepreneurial cooperation (Lozano, 2008; and going a bit further to suggest the concept and a model of sustainable entrepreneurship Young \& Tilley, 2006). Taking into consideration the concepts and ideas up to now presented it is possible to propose a cycle with all these concepts.

Figure 1: From Entrepreneurship to Sustainability: A Proposed Cycle

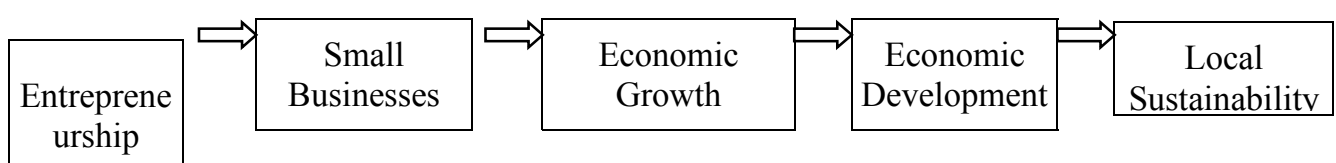


Since local development (sustainability) is supported by local innovative agents (entrepreneurs), policy making responsible must pay attention to the region and local economic activity. The relation between region and local agents lead us to the concept of embeddedness, which means the intangible resources that result from the close relation between the local and the agents. Figure 1 presents this relation among all these concepts and is also a visual summary for the ideas presented along this chapter. After the theoretical concepts it is important to know the region where this study was realized.

\section{The Region}

The region where this study was realized is formed by six municipalities (Castelo de Paiva, Felgueiras, Lousada, Paços de Ferreira, Paredes, Penafiel). This region is located in the North of Portugal, and for statistical purposes is a region within NUTE III - Tâmega. According to INE (2008) this region has 338.000 inhabitants with a relatively high percentage of young people.

Economically as most of the country, the primary sector was in the past the main activity. Other activities such as manufacturing or services have been assuming a more relevant role. Nowadays the main activities in this region are: shoes making, textile, wood furniture and construction. In four of the six municipalities it is even possible identify some industrial clusters as referred by Bessa (2004) and DHVMC (2004): Felgueiras: Shoes production; Lousada: Textile; Paços de Ferreira and Paredes: Wood furniture.

To describe the entrepreneurial fabric it was necessary to collect information from different institutions, since the available information varies from source to source. By using data from Statistics National Institute, this region had 34.049 firms registered in 2005. However information from CofaceMOPE reveals the existence of 11.973 firms and according to the Work Ministry the number of firms is 10.231. After some conversations with local entities, it was realized that there is no valid information about the exact number of firms, and it was assumed, that a value of 12.000 firms should be very close to the reality.

The following step was an analysis of firm distribution according to activity sectors. This distribution (relative values), considering data from the three institutions is similar, pointing as main activities retailing, manufacturing, and construction sectors. Together they represent $75 \%$ of firms in this region.

However to analyse management strategies, entrepreneurial and innovative actions of firms from different sectors is difficult by using a single approach to all of them. As Schwartz, Birch, \& Teach (2007) argue the degree and type of entrepreneurship differs from a clothing store to a technology software industry (even on the adopted 
strategies). In order to find more significant results it was decided to limit this study to industrial (manufacturing and mining and quarrying firms) and construction businesses. This choice can be justified by the number of firms that is almost $50 \%$ of the total number of firms, and $75 \%$ of total employment. According to the data provided from the three institutions it was verified that the number of firms in industrial and construction sectors are around 5.000 (this figure will be used as the total population for this study).

On what regards firms' dimension, according to the data provided by CofaceMOPE, it is possible to verify that this region does not present the usual distribution, where micro firms present an overwhelming percentage. In this region they are still the largest class with $62 \%$ (in Portugal this figure is around 80 percent) and small firms represent $35 \%$. Together they account for $97 \%$ which is within the class distribution found in Portugal. The remaining 3\% are classified as medium-sized firms (large firms were not considered). However, considering the data provided from the Work Ministry micro reach $79 \%$ (considering only the criteria of less than 10 employees) and $85 \%$ (considering the criteria of a turnover up to 2 million Euros).

This region can be described as a usual Portuguese or even European region, where small firms (micro and/or small) are the largest number of firms based mainly on intensive work that does not require high qualifications. This scenario also played some importance on the elaboration of the questionnaire that is described on the next chapter.

\section{The Questionnaire}

Bearing in mind the subjects under discussion along this paper the general hypothesis to test can be presented in two steps: (1) How innovative (on management level) are firms in this region? (2) How strong is the relation between innovative management and local sustainability? In order to get the necessary results to proceed with this study, considering the alternative options and some experience from past studies the questionnaire seemed to be the best solution. Considering the literature review theories, ideas and suggestions Table 1 was elaborated as a support to the questionnaire.

Table 3: Initial Research for Questionnaire Elaboration

\begin{tabular}{|l|l|l|}
\hline \multicolumn{1}{|c|}{$\begin{array}{c}\text { Theory } \\
\text { (References) }\end{array}$} & \multicolumn{1}{c|}{ Hypothesis } & \multicolumn{1}{c|}{ Questions } \\
\hline \multicolumn{3}{|c|}{ ENTREPRENEURSHIP } \\
\hline $\begin{array}{l}\text { Miller (1983); } \\
\text { Lumpkin \& Dess } \\
\text { (1996); Dean, } \\
\text { Thibodeaux, }\end{array}$ & $\begin{array}{l}\text { Entrepreneurship is } \\
\text { analyzed through } \\
\text { (1) INNOVATION }\end{array}$ & $\begin{array}{l}\text { (1) Product Innovation } \\
\text { (1) Process and/or marketing; } \\
\text { (2) In order to get good results it is usual to } \\
\text { take risks; }\end{array}$ \\
\hline
\end{tabular}




\begin{tabular}{|c|c|c|}
\hline $\begin{array}{l}\text { Beyerlein, Ebrahimi, } \\
\text { \& D. (1993); Dess, } \\
\text { Lumpkin, \& Covin } \\
\text { (1997); Beaver } \\
\text { (2002); Schumpeter } \\
\text { (1934); Knight } \\
\text { (1921); ... }\end{array}$ & $\begin{array}{l}\text { PROPENSITY } \\
\text { (3) PROACTIVITY }\end{array}$ & $\begin{array}{l}\text { (2) Before a new negotiation/business } \\
\text { success probabilities are analyzed; } \\
\text { (3) Firm has a significant influence level } \\
\text { on its activity sector } \\
\text { (3) Firm follows the market tendencies; }\end{array}$ \\
\hline \multicolumn{3}{|c|}{ STRATEGY } \\
\hline \multicolumn{3}{|c|}{ Internal Strategy } \\
\hline CE (2000) & $\begin{array}{l}\text { Human resources } \\
\text { skills }\end{array}$ & $\begin{array}{l}\text { Employees present low skills levels; } \\
\text { Human resources qualification is required } \\
\text { and promoted by firm managers; }\end{array}$ \\
\hline $\begin{array}{l}\text { Entrialgo et al. } \\
\text { (2000); Man et al. } \\
\text { (2001); Malone } \\
(2004)\end{array}$ & Strategic Analyzes & $\begin{array}{l}\text { Stakeholders play an important role on firm } \\
\text { management and business planning; }\end{array}$ \\
\hline $\begin{array}{l}\text { Man et al. (2001); } \\
\text { Entrialgo et al. } \\
\text { (2000); Bruce } \text { et al. } \\
\text { (1999); Ad_Capita } \\
\text { (2002); David } \\
\text { (1986); Ibrahim } \\
\text { (1991); Kargar } \\
\text { (1996); Olson \& } \\
\text { Boker (1995); } \\
\text { Kerns (2002); } \\
\text { Velho (2003) }\end{array}$ & Strategic Planning & $\begin{array}{l}\text { Most of employees participated on } \\
\text { decisions about their sectors; } \\
\text { It exists a cooperation and collaboration } \\
\text { among different firm activities; } \\
\text { Work in this firm means to be part of a } \\
\text { team; } \\
\text { Strategic decisions are a result of } \\
\text { departments discussion and collaboration; }\end{array}$ \\
\hline Equal to previous & Short/long run & $\begin{array}{l}\text { Long-run is more important than short-run; } \\
\text { Firm adopts a low cost strategy; }\end{array}$ \\
\hline $\begin{array}{l}\text { Inforegio (2000); } \\
\text { CE (2000); } \\
\text { Caloghirou et al. } \\
\text { (2004); } \\
\text { Magretta (2004) }\end{array}$ & Strategic flexibility & $\begin{array}{l}\text { Firm strategy is adapted according to } \\
\text { feedback received from the market; }\end{array}$ \\
\hline \multicolumn{3}{|c|}{ External Strategy } \\
\hline $\begin{array}{l}\text { Freire (1997); } \\
\text { Hasegawa (2003); } \\
\text { Ad_Capita (2002); } \\
\text { Rosenfeld (1996); } \\
\text { Mytelka (1991); } \\
\text { Sarkar et al. (2001): } \\
\text { Greeve (1995) }\end{array}$ & $\begin{array}{l}\text { External } \\
\text { Cooperation }\end{array}$ & $\begin{array}{l}\text { Firm is a member of one or more } \\
\text { entrepreneurial association; } \\
\text { Collaboration with other firms is frequent; } \\
\text { Firms can take advantages from an } \\
\text { entrepreneurial cooperation network; }\end{array}$ \\
\hline $\begin{array}{l}\text { EC (2004); } \\
\text { Voudouris et al. } \\
\text { (2000); } \\
\text { Beaver (2002) }\end{array}$ & Markets & $\begin{array}{l}\text { Firm market is a local, national or } \\
\text { international market? } \\
\text { Firm plays in B2B or B2C? }\end{array}$ \\
\hline
\end{tabular}




\begin{tabular}{|c|c|c|}
\hline $\begin{array}{l}\text { Malone (2004) } \\
\text { GEM }\end{array}$ & Opportunity & $\begin{array}{l}\text { New businesses are planned and created } \\
\text { during economic crisis periods; } \\
\text { When results are as expected it is not } \\
\text { necessary to exploit new opportunities; }\end{array}$ \\
\hline $\begin{array}{l}\text { Voudouris et al. } \\
(2000) \\
\text { Porter (1985) } \\
\end{array}$ & Selling strategies & $\begin{array}{l}\text { Firm presents a good CRM; } \\
\text { Firm adopts a low-price strategy; }\end{array}$ \\
\hline \multicolumn{3}{|c|}{ LOCAL SUSTAINABILITY (Sustainable Development) } \\
\hline $\begin{array}{l}\text { Cheshire \& Malecki } \\
\text { (2004); } \\
\text { Vargas (2000); } \\
\text { Helmsing (2003); }\end{array}$ & $\begin{array}{l}\text { SME and local } \\
\text { development }\end{array}$ & $\begin{array}{l}\text { Firms play an important role on local } \\
\text { development; } \\
\text { By disrespecting some rules my firm is not } \\
\text { harming the environment; }\end{array}$ \\
\hline $\begin{array}{l}\text { CE (2002a) } \\
\text { Helmsing (2003) }\end{array}$ & $\begin{array}{l}\text { Economic } \\
\text { development }\end{array}$ & $\begin{array}{l}\text { Small firms are those who can present a } \\
\text { greater contribution for region } \\
\text { development; } \\
\text { Firm main goal is profit and value added; } \\
\text { Firm results are reinvested on firm } \\
\text { necessities or in the region; }\end{array}$ \\
\hline $\begin{array}{l}\text { Cuthill (2002) } \\
\text { Rajeswar (2000) } \\
\text { Williams (2002) } \\
\text { CE (2002) }\end{array}$ & Social development & $\begin{array}{l}\text { Firm employees are living on an area of } \\
20 \mathrm{~km} \text { of firm; } \\
\text { When hiring men and women have equal } \\
\text { opportunities; } \\
\text { All firm works are done by adults; } \\
\text { Firm supports employees or local } \\
\text { associations; } \\
\text { Firm supports society by sponsoring } \\
\text { cultural events; }\end{array}$ \\
\hline $\begin{array}{l}\text { Bergström \& Dobers } \\
(2000) ; \text { Devuyst } \\
(2000) ; \text { Lothe } \\
(2001) ; \text { CE }(2002) \\
\text { Oliveira }(2005)\end{array}$ & $\begin{array}{l}\text { Environmental } \\
\text { development }\end{array}$ & $\begin{array}{l}\text { Firm tries to know and to reduce the } \\
\text { impacts caused on soils, water and } \\
\text { environment; } \\
\text { Firm chooses clean technologies; } \\
\text { Firm knows the environmental long run } \\
\text { impacts that today's decision may bring; }\end{array}$ \\
\hline CE (2002) & Community & $\begin{array}{l}\text { Community support are frequent and are a } \\
\text { firm policy; }\end{array}$ \\
\hline
\end{tabular}

Since there was no viability to interview the total population (5.000 firms) the study was taken by using a valid sample. In order to calculate the sample size Saunders, Lewis, and Thornhill (2006) present a formula that considers the variability of the factors to be studied, the confidence interval required, and the error margin. The formula is:

$n=p \% * q \% *[z / e \%]^{2}$ 
where:

$n$ : minimum sample size required;

$p \%$ : proportion belonging to the specified category;

$q \%$ : proportion not belonging to the specified category;

$z: \mathrm{z}$ value corresponding to the level of confidence required:

$e$ : margin of error required;

According to Saunders et al. (2006), when the population is less than 10.000 a smaller sample can be used without affecting the accuracy. The adjusted formula is:

$n^{\prime}=\{n /[1+(n / N)]\}$

where:

$n$ ': adjusted minimum sample size;

$n$ : the minimum sample size (as calculated above);

$N$ : total population;

Considering strategic entrepreneurship as the main factor, and a variability of $80-$ 20 (result obtained on a pilot study of 33 observations which was corroborated later with the final results) it was obtained a $n=245,86$ and a $n^{\prime}=235,47$, which means that are necessary $\mathbf{2 3 6}$ questionnaires the get a valid result for the population by using a sample.

After a presentation of the main concepts, the region, and the methodology followed for the questionnaire the next step is to present the results achieved through the questionnaire.

\section{Some Results Entrepreneurship}

Based on the literature presented on chapter 1 and following the methodology presented on chapter 3, it is now possible to present some results on entrepreneurship on the region of Vale do Sousa.

As presented on the literature review the degree of entrepreneurship (or intrapreneurship) was measured taking into consideration three factors: innovation, risk and proactivity. In order to measure innovation it was presented a table with 14 strategies that could score for 20 points. It was asked to the interviewees to mark the strategies that firm had been following on the last years. In order to classify each firm on innovation degree were created 5 classes ( 3 classes from 0 to 9 points and two classes from 10 to 20 points). The reason to create different classes is related with the high percentage of firms that scored 9 or less points $(87 \%)$. The global results are as follows: 
Figure 2: Innovation Strategies Classification

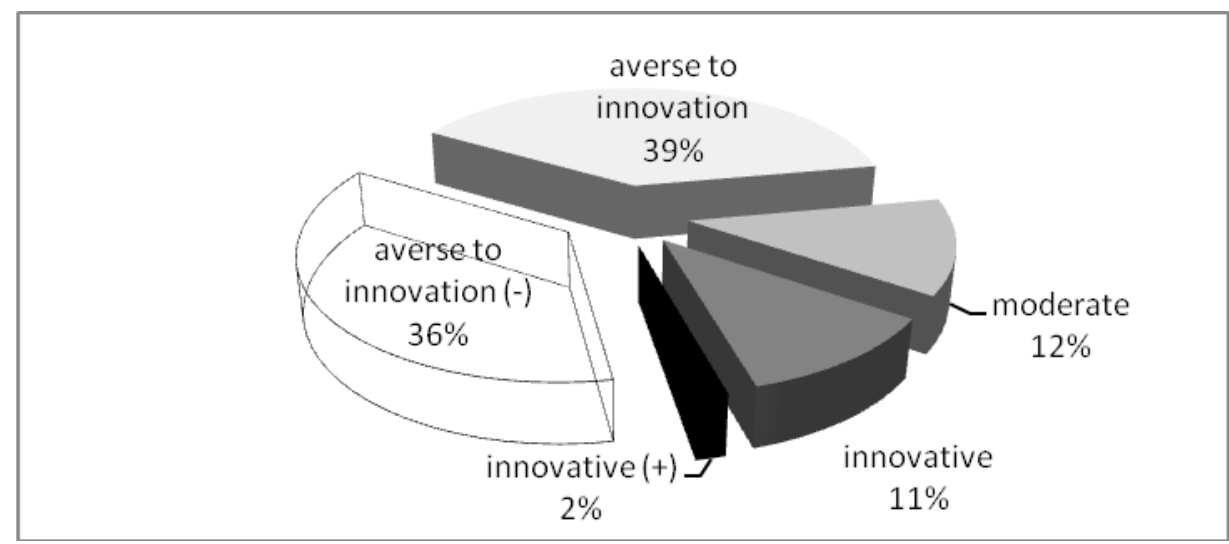

From Figure 2 it is possible to verify that only $13 \%$ of firms present an innovative strategy (innovative or innovative $(+)$ ) and $12 \%$ present a moderate approach. It is important to mention that moderate approach to innovation is a result under 10 points (in a 20 score possible). Most of firms (75\%) present averse strategies to innovation (averse to innovation and averse to innovation (-)). This allows us to conclude that there is not an innovation strategy tendency on these firms.

It is also possible to present the main strategies followed by these firms. In first place scoring $19 \%$ firms choose a strategy of "investment in new equipments" followed by a strategy of "productive process reorganization" (14\%) and with the same importance (14\%) a strategy of "selling outside firms' usual markets". From these simple analyses it can be concluded that firms do not present very important innovations, but those that are more frequent or even necessary to keep firm sustainability. Considering cooperation strategies that were also presented on the questionnaire it is possible to conclude that they are very rare, and mainly on a vertical (forward or backward) basis, being the value very close to zero on a horizontal basis.

This brief analysis to innovation procedures allows us to conclude that firms present a low level of innovation on their management and just a few firms present a significant number of innovation strategies. This result does not match with the conclusions presented on OECD (2002) where Portuguese small industrial firms were classified as innovators.

Proceeding to the risk analysis it was followed the same methodology as innovation analysis. Now the risk strategies could score at a maximum of 10 points. The results are presented on Figure 3. 
Figure 3: Risk Strategies Classification

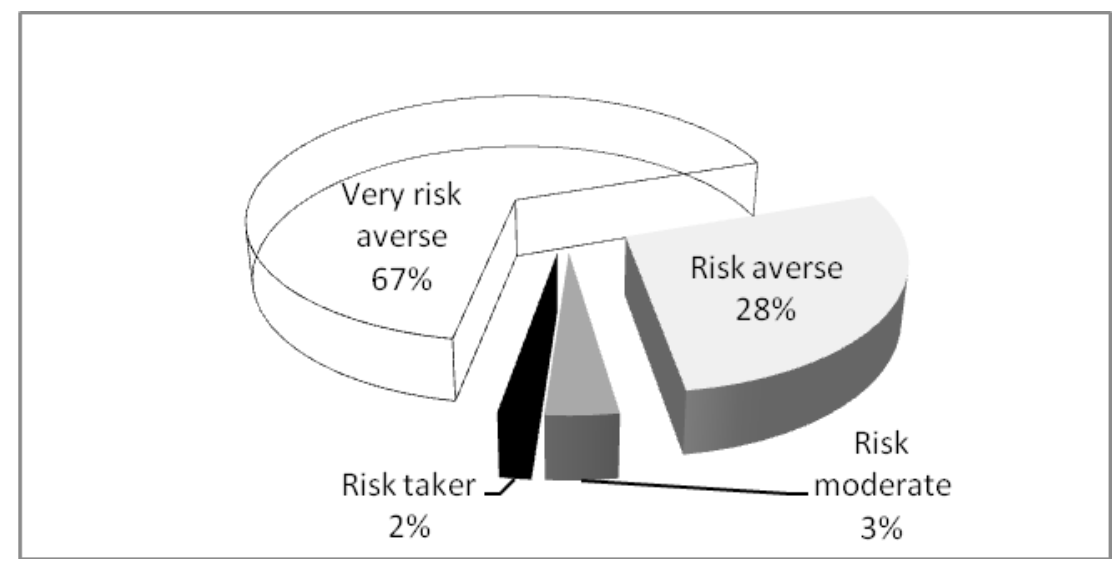

The results from risk analysis are similar from those obtained on innovation analysis, $67 \%$ of firms present a very high level of risk aversion which means that on the last years they adopted a maximum of 2 risk strategies. There are still $28 \%$ of firms that adopted 2 to 4 risk strategies that can be classified as risk averse which means that $95 \%$ of firms in this region present a risk aversion management. Considering risk taker and moderates it is obtained a result of only $5 \%$.

The most frequent risk strategies are "quality investments" $(31,9 \%)$ and "new customers demand satisfaction" (26,4\%). It is important to notice that both strategies are almost risk free, since to survive firms must invest on quality and satisfy their customers. At the same time a strategy of financing through other means than own capital, bank credit, or subsidies presented a result of $13,8 \%$ which means that is possible the existence of informal financing and firms support programs (namely European supports) may not be designed to meet firms needs. These results do not differ from innovation analysis, because if it was possible to conclude that there is a lack of innovation strategies, there also is a lack of risk strategies.

After innovation and risk the next step is to analyze proactivity behavior on these firms. This analyze was measured through a latent variable by using a group of indicators related with proactivity. The used indicators for proactivity were the following:

- Employees qualifications,

- Employees professional education,

- Long-run versus short-run management,

- Opportunities future exploitation versus present exploitation,

- CRM organization. 
In order evaluate the results was measured the cronbach alpha, but the results were not favorable since this test present a result lower than 0,6 which means that there exist a risk of inconsistency among these indicators. Since the indicators resulted from the literature review, and all of them are in one or another way related to proactivity even with this coronach alpha result these indicators were used to analyze proactivity degree.

Considering the five proactivity indicators it was obtained an average result of 3,49 (the indicators were analyzed on a 1 to 5 Likert scale). This result seems to be much better than those obtained on innovation and risk analyses, but in order to get all of them on the same scale, innovation and risk results were standardized with proactivity. Recoding the two first factors (innovation and risk) on a 1 to 5 scale the results present an average of 1,27 on innovation and 1,06 on risk which validates the perception that proactivity presented a better result.

These results allow us to conclude that firms accept changes but only on aspects that can bring profits on the short term. They act proactively probably because they expect a positive reaction from the market, but they do not innovate and do not take risks on their management, they do not welcome changes on structural aspects that can affect firms' future. This conclusion goes with Avlonitis \& Salavou (2007) where identified two groups of entrepreneurs classified as active and passive entrepreneurs were. The first present a higher risk propensity but both groups are proactive on new product or new market approaches.

Considering the results presented up to now was calculated the degree of entrepreneurship obtaining in first place an average result of 1,94 (on a 1 to 5 scale). After that by using SPSS software each case was recoded in order get entrepreneurship classes. From this recoding it was possible to create 5 entrepreneurship classes as follows:

Figure 4: Entrepreneurship Levels

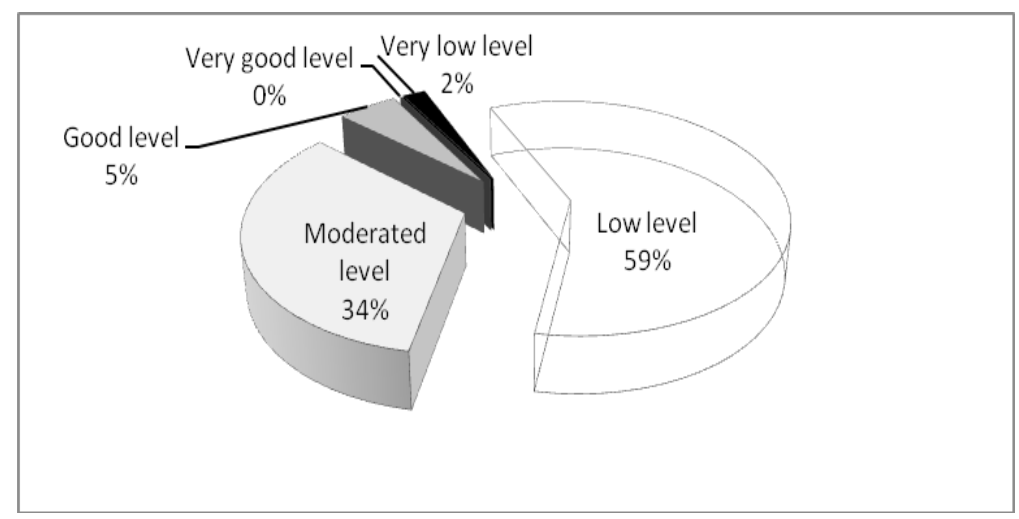


The percentages presented on Figure 4 reveal the relation that firms in the region of Vale do Sousa present towards entrepreneurship. Most of them (59\%) present a low level of entrepreneurship and the $0 \%$ of firms with a very good level is real because there are no firms classified at this class. Only $5 \%$ present a good level of entrepreneurship, and we must remind that these values are supported by the good results of proactivity.

As a summary about entrepreneurship it is possible to say that firms present a very low level of innovation and risks on their management and strategy decisions which allow classifying those firms as risk and innovation averse. On what concerns proactivity the results are more favorable to entrepreneurship. The combination of these three factors lead to a high percentage of firms classified with a low level of entrepreneurship (59\%) and 34\% present a moderate level.

It is also important to refer that analyzed measures considered management actions and decisions (strategic entrepreneurship or intrapreneurship). These analyses were done because is on day to day management that firms may contribute for local sustainability.

\section{Local Sustainability}

After some considerations about the concepts of entrepreneurship and entrepreneurships some considerations and results about local sustainability will now be presented. On this subject the questionnaire were presented on a Likert scale (1 to $5)$.

This section of the questionnaire was organized in three main areas of sustainable development. The first question was a general approach to the role of firms on local development: "Firms play an important role on local development". On a possible classification from 1 to 5 the average answers presented a value of 4,38, which means that interviewees, most of them with managerial responsibilities, present a perception that firms are important agents on local development. It is interesting to notice that from all answers the minimum value obtained was 2 , which means that no one disagrees with the important role that firms play on local sustainability. The following questions were analysed in groups of variables, following the methodology used on proactivity analyses that was presented by Hill \& Hill (2002): latent variables. To analyze both the economic and social dimension it was used two groups of three questions, and two questions for environmental groups.

The economic dimension was analyzed through the questions:

- Small firms are those who may have the largest contribution for local development;

- Firm profits must be reinvested on the firm;

- Firm profits must be reinvested on the region; 
Even recognizing the important role of firms on local development $(4,38)$ interviewees do not recognize this importance on small firms since the average result for the first economic dimension question was 3,63. It means that small firm managers understand that their larger incumbents have more responsibility on local development. Considering the answers to question 2 and 3 the average results were 3,98 for firms profit reinvestment and 3,31 for region profit reinvestment. These results also show that firm factors present higher values than regional ones. This might mean that managers are more concerned with the economic dimension.

By doing an analyzes to the economic dimension was obtained an average result of 3,64 . Since this is the first result, some final comments will be done after analyzing the two other dimensions in order to have an idea about sustainability.

The social dimension was analyzed through the questions:

- Most of employees are living on firms' region;

- All firm works, even outsourced parts, are done by adults;

- Firm must support society through sponsorship actions developing social and cultural actions on a regularly basis;

Analyzing the questions as one variable, it is possible to get the results about the social dimension that is 3,76 . According to the literature on sustainable development this is not a normal result (higher than economic dimension) since most authors defend that usually firms and even governments are putting more efforts on the economic dimension.

The environmental dimension was analyzed through the questions:

- Firm knows and tries to reduce environmental impacts (soil, air and water);

- If some environmental rules will not be respected by this firm, there is no impact on the environment;

The average result for both questions is 4,03 that is the highest value from the three dimensions. This demonstrates the importance that firm managers are giving to the green dimension. But are the actions of these firms really in agreement with these results? This question opens new paths for further research.

Considering all dimensions the average result presents a value of 3, 81 which means that on average firms in the region of Vale do Sousa, present a positive, let's say, proactive attitude towards to sustainability. Considering each firm result and forming classes where the lower means a weak approach to sustainable development and the highest a strong approach we can see that most of firms, $96 \%$, present a proactive attitude to sustainable development. 
Figure 5: Sustainability Levels

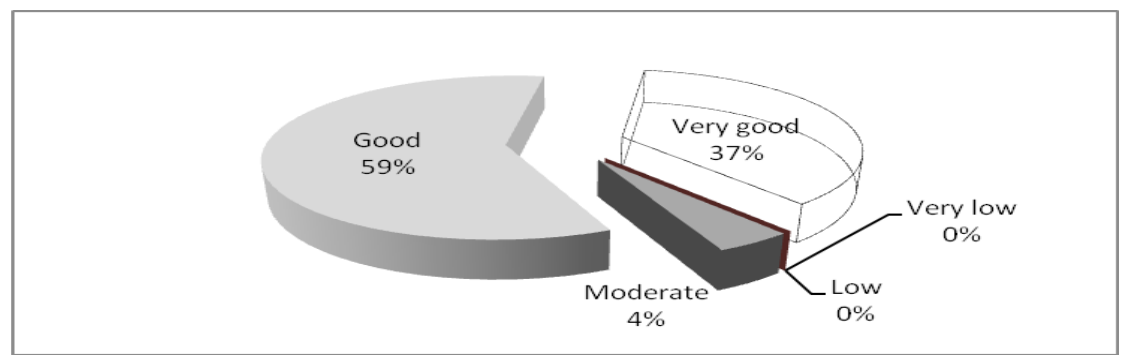

Considering the results obtained on entrepreneurship analyses where firms presented a low level of entrepreneurship the results now obtained were not expected. As it is possible to see on Figure 5 most of firms $(96 \%)$ present a good or very good level of sustainability. The two lowest classes do not include any firm, which means that all firms present at least a moderate approach to sustainability. These results allow us to conclude that firms on the region of Vale do Sousa, promote a development that can be classified as sustainable. Disagreeing with the idea presented by most authors that argue that the division of sustainable development in three areas is an excuse to pay more attention to the economic dimension, the results now obtained show that economic dimension is the last area to be considered by firm management.

\section{The Relationship Between Entrepreneurship and Local Sustainability}

Having the results on entrepreneurship and sustainability it is possible to analyze the relation between both of them trying to present an answer to this paper title: Is there any relation between entrepreneurship and sustainability? Are the most entrepreneurial firms playing a major role on local sustainability?

Considering an average degree of 1,94 to entrepreneurship level and 3,81 for sustainability by using some econometric tools through SPSS it was analyzed the relation between them. In first place it was done a bivariate scatter plot with both variables (entrepreneurship and development). The graph presented a dispersion that did not indicate any pattern or typical behaviour. After that, and since we were looking for a pattern some regressions were tested, but the results pointed on the same way that the previous analysis. Considering the, Linear, Logarithmic, Inverse, Quadratic, Cubic, Compound, Power, S, Growth, Exponential and Logistic regressions, it was verified that the highest value obtained for $\mathrm{R}^{2}$ was $20,9 \%$ with the Cubic Regression, however this is an extremely low value. Even being one of the most flexible regression models, with such a low $\mathrm{R}^{2}$ it is worthless to analyze the regression parameters, since the conclusions would not be valid. As it is possible to see on Figure 6 none of the regression lines fit on the scatter plot that considers entrepreneurship and development. 
Figure 6: Regression Lines on the Scatter Plot (entrepreneurship - development)

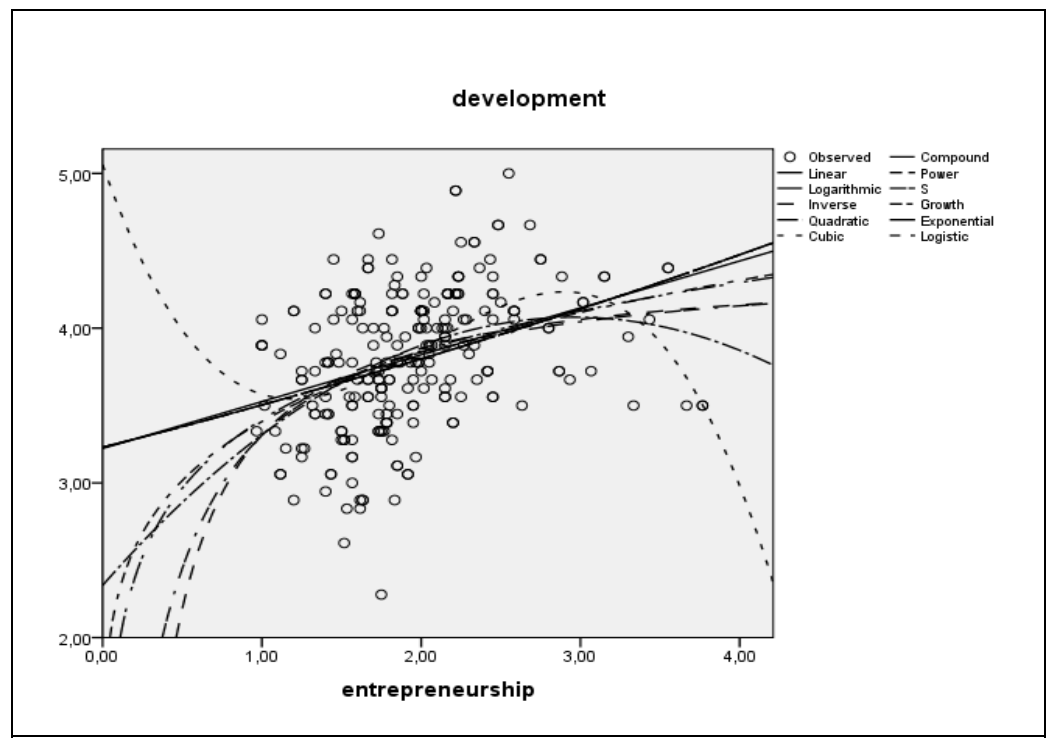

The conclusion that can be drawn out from these results is that firms in the region of Vale do Sousa, do not present an entrepreneurial management but they still present a proactive approach to sustainable development. In this case is not possible at all to talk about the concept of sustainable entrepreneurship.

\section{Conclusion}

Along this paper it was developed and present some theoretical and practical concepts about entrepreneurship and sustainability on the region of Vale do Sousa. In order to get some conclusions were studied small firms on the industry and construction sectors.

Supported by the literature review a questionnaires was designed and presented to 251 firms in order to evaluate their intrapreneurial behaviour by studying three key concepts (innovation, risk and proactivity) and local sustainability by studying the concepts associated to sustainable development (economic, social, and environmental).

From entrepreneurship analyses it was possible to conclude that firms present a low level of intrapreneurship that result from an innovation and risk aversion management. Even with a low degree of innovation and risk, these firms management can be classified as proactive, which means some openness to change but only on aspects that can bring results on the short-run. 
With these results it was expected to have a low level of local sustainability from these firms. However the results were surprising. Considering the dimensions analyzed in order to measure sustainable development, the results were: Economic: 3,64; Social: 3,76; Environmental: 4,03. According to the literature review some authors argue that the division of sustainable development concept into three dimensions is an excuse in order to focus on the economic dimension. In the present study the results pointed in the opposite way, apparently firms in the region of Vale do Sousa are more concerned with the environmental and social dimensions than economic one.

Since this shows an opposite tendency to the literature review, it requires some further research. In order to analyze each dimension there are some other variables that can be taken into consideration that were not considered on the present study. A further research suggestion is to build a battery of indicators for each dimension according to the literature review in order to analyze those variables on the region of Vale do Sousa, to accept or reject the results here presented. Among many other factors, the study of firms' stakeholders must be taken into consideration in order to get a different perspective from the firm.

On what regards entrepreneurship and sustainability it was possible to conclude, that there is no relation, which means that in this region is difficult to talk about sustainable entrepreneurship. On the contrary to what could be expected, entrepreneurship degree (strategic entrepreneurship) is very low, while local sustainability present very good results. In this last situation, it will be important to develop further research in order to evaluate this region sustainability.

\section{References}

Abouzeedan, A. and Busler, M. (2004), "Typology Analysis of Performance Models of Small and Medium-Size Enterprises (SMEs)", Journal of International Entrepreneurship, 2: 155-177.

Acquaah, M. (2007), "Managerial social capital, strategic orientation, and organizational performance in an emerging economy", Strategic Management Journal, 28: 1235-1255.

Acs, Z.J. \& Catherine, A. (2004), Employment growth and entrepreneurial activity in cities, University of Baltimore.

Ad_Capita, (2002), Pode a gestão portuguesa competir? In S. o. M. Ad Capita International Search \& Cranfield University (Ed.), Lisboa, Londres: Ad Capita, Recursos Humanos, Lda.

Antoncic, B. and Hisrich, R.D. (2001), "Intrapreneurship: Construct refinement and cross cultural validation", Journal of Business Venturing, 16: 495-527.

Ardichvili, A., Cardozo, R. and Ray, S. (2003), "A theory of entrpreneurial opportunity identification and development", Journal of Business Venturing(18): 105-123. 
Arend, R.J. (2006), "SME-Supplier alliance activity in manufacturing: Contingent benefit and perceptions", Strategic Management Journal, 27: 741-763.

Avlonitis, G.J. and Salavou, H.E. (2007), "Entrepreneurial orientation of SMEs, product innovativeness, and performance", Journal of Business Research, 60: 566-575.

Baptista, R. and Carias, C. (2007), "Job creation and destruction by small businesses in the Portuguese regions", 47th Congress of European Regional Science Association. Paris, France.

Beaver, G. (2002), "Small Business, Entrepreneurship and Enterprise Development" (1st edition ed.): Financial Times - Prentice Hall.

Bergström, O. and Dobers, P. (2000), "Organizing sustainable development: From diffusion to translation", Sustainable Development, 8: 167-179.

Bessa, D. (2004), PRASD - Programa de Recuperação de Áreas e Sectores Deprimidos: Ministério da Economia, União Europeia, PRIME,.

Bratnicki, M. (2005), "Organizational entrepreneurship: Theoretical background, some empirical tests, and directions for future researches", Human Factors and Ergonomics in Manufacturing, 15 (1): 15-33.

Brower, M.T. (2002), "Weber, Schumpeter and Knight on entrepreneurship and economic development", Journal of Evolutionary Economics, 12: 83-105.

Bruce, M., Cooper, R., and Vazquez, D. (1999), "Effective design management for small businesses", Design studies, 20: 297-315.

Bruyat, C. \& Julien, P.A. (2000), "Defining the field of research in entrepreneurship", Journal of Business Venturing, 6: 165-180.

Caloghirou, Y., Protogerou, A., Spanos, Y., and Papagiannakis, L. (2004), "Industry-Versus Firm-specific Effects on Performance: Contrasting SMEs and Large-sized Firms", European Management Journal, 22(2): 231-243.

Cantillon, R. (1755), Essai sur la Nature du Commerce en Général (The Nature of Trade in General), Paris: Institut National D'études Démographiques.

CCE (2003), Livro Verde: Espírito Empresarial na Europa. Bruxelas: Comissão das Comunidades Europeias.

CE (2000), Quadro Comunitário de Apoio 2000-2006.

CE (2002), PME em foco - Principais resultados do Observatório das PME Europeias 2002. Luxemburgo: Comissão Europeia.

Chagas, O.J. (1999), "A tomada de decisão segundo o comportamento empreendedor: Resultado de uma survey na região das missões", Unpublished Project, Universidade Federal do Rio Grande do Sul.

Cheshire, P.C. and Malecki, E.J. (2004), Growth, development, and innovation: A look backward and forward. Papers in Regional Science, 83: 249-267.

Craig, B., Jackson, W. and Thomson, J. (2005), On SBA-guaranteed lending and economic growth. In S. Shane (Ed.), Economic Development Through Entrepreneurship: 127 150. Cheltenham, UK: Edwad Elagar.

Cuthill, M. (2002), "Exploratory Research: Citizen participation, local government and sustainable development in Australia", Sustainable Development, 10: 79-89.

David, W. (1986), "Business strategies in smaller manufacturing firms", Small Business Management, 24(1): 38-46.

Dean, C.C., Thibodeaux, M.S., Beyerlein, M., Ebrahimi, B. and D.M. (1993), "Corporate Entrepreneurship and Competitive Agressiveness: a comparison of U.S. firms opertating in Eastern Europe or the Commonwealth of independent States with U.S. firms in other 
high risk environments", in Prasard, S.B. (Ed.), Advances in International and Comparative Management, pp. 31-54, Greenwich, JAI Press.

Dess, G.G., Lumpkin, G. and Covin, J. (1997), "Entrepreneurial strategy making and firm performance: test of contingency and configurational models", Strategic Management Journal, 18(9): 677-695.

Devuyst, D. (2000), "Linking impact assessment and sustainable development at the local level: The introduction of sustainability assessment systems", Sustainable Development, 8: 67-78.

Drucker, P.F. (1985), Innovation and entrepreneurship, New York, Harper Business.

Duarte, M. (2007), A empresa sustentável como instrumento do desenvolvimento sustentável, "Revista da Câmara dos Técnicos Oficiais de Contas TOC": 56.59, Lisboa: TOC.

EC (2004), "SMEs in Europe, 2003”, In O. o. E. SMEs (Ed.), Observatory of European SMEs, Luxembourg: European Commission.

Eckhardt, J.T. and Shane, S. (2003), "Opportunities and entrepreneurship", Journal of Management, 29(3): 333-349.

Entrialgo, M., Fernandéz, E., and Vázquez, C.J. (2000), "Linking entrepreneurship and strategic management: Evidence from Spanish SMEs", Technovation, 20: 427-436.

Espinosa, A., Harnden, R., \& Walker, J. (2008), "A complexity approach to sustainability Stafford Beer revisited”, European Journal of Operation Research, 187: 636-651.

Eversole, R. (2003), "Help, Risk and Deceit: Microentrepreneurs talk about microfinance", Journal of International Development, 15: 179-188.

Freire, A. (1997), Estratégia - Sucesso em Portugal (1st ed.), Lisboa: Editorial Verbo.

Gartner, W. B. 1988. "Who is the entrepreneur? Is the wrong question", The American Journal of Small Business, 12(4): 11-32.

GEM. (2008), Global entrepreneurship Monitor: 2008 Executive Report, Babson, Universidad del Desarrollo.

Greeve, A. (1995), "Networks and entrepreneurship - An analysis of social relations, occupational background, and use of contacts during the establishment process", Scandinavian Journal of Management, 11(1): 1-24.

Hamel, G. and Prahalad, C.K. (1997), Competindo pelo futuro ${ }_{2}$ São Paulo, 4 reimp.

Hasegawa, H. (2003), "Survival and strategy of small/micro firms", The International Journal of Asia Management, 2(1): 65-79.

Hayton, J.C. and Kelly, D.J. (2006), "A competency-based framework for promoting corporate entrepreneurship", Human Resources Management, 45(3): 407-427.

Helmsing, A.H.J.B. (2003), "Local Economic Development: New Generations of Actors, Policies and Instruments for Africa", Public Administration and Development, 23: 6776.

Hill, M. M. and Hill, A. (2002), Investigação por Questionário, Lisboa, Edições Silabo.

Hu, M.W. (2003), “Many small antelopes make a dragon”, Futures, 35: 379-392.

Hubler, E., Zaghni, E.S., and Mussi, C.W. (2003), Uma reflexão sobre o papel do empreendedor na organização e a complexidade ambiental do processo estratégico.

Ibrahim, A.B. (1991), "Strategy types and small firms' performance: An empirical investigation", Small Business Strategy, 4(1): 13-22.

INE (2008), "Estimativas provisórias de população residente Portugal, Nuts II, Nuts III, Municípios", In I. N. d. Estatísitica (Ed.), Lisboa, Instituto Nacional de Estatísitica.

Inforegio, Sixth periodic report on the social and economic situation and development of regions in the European Union. 
Kargar, J. (1996), "Strategic planning systems characteristics and planning effectiveness in small mature firms", Mid Atlantic Journal Business, 32(1): 19-34.

Kerns, C.D. (2002), "An entrepreneurial approach to strategic direction setting”, Business Horizons: 2-6.

Kerr, I.R. (2006), Leadership strategies for sustainable SME operation. Business Strategy and the Environment, 15: 30-39.

Kim, K.S., Knotts, T.L., and Jones, S.C. (2008), "Characterizing viability of small manufacturing enterprises (SME) in the market", Expert Systems with Applications, 34: 128-134.

Kirzner, I.M. (1973), Competition and entrepreneurship, Chicago, University of Chicago Press.

Knight, F. H. (1921), Risk, uncertainty and profit, New York, Houghton Mifflin.

Kyrö, P. (2000), "Entrepreneurship in the post modern society", Wirtschaffs Politische Blätter, 47: 37-45.

Lawrence, S.R., Collins, E., Pavlovich, K., and Arunachalam, M. (2006), "Sustainability practices of SMEs: The case of NZ", Business Strategy and the Environment, 15: 242257.

Lothe, S. (2001), "Contradictions between WTO and Sustainable Development? The case of environmental dumping", Sustainable Development, 9: 197-203.

Lozano, R. (2008), "Developing collaborative and sustainable organizations", Journal of Cleaner Production, 16: 499-509.

Lumpkin, G. and Dess, G.G. (1996), "Clarifying the entrepreneurial orientation construct and linking it to performance", Academy of Management Review 21(1): 135-172.

Lumpkin, G. \& Dess, G.G. (2001), "Linking two dimensions of entrepreneurial orientation to firm performance: the moderating role of environment and industry life cycle", Journal of Business Venturing, 16: 429-451.

Magretta, J. (2004), “O Grau Zero da Gestão", Ideias \& Negócios: 66-67.

Malone, M.(2004), "The small business ego trap", Business Horizons, 47(4): 17-22.

Man, T.W.K., Lau, T. and Chan, K.F. (2001), "The competitiveness of small and medium enterprises. A conceptualisation with focus on entrepreneurial competencies", Journal of Business Venturing (17): 123-142.

Melo, J.P.B. (2002), “A problemática e as políticas de desenvolvimento local. In J. S. costa (Ed.)", Compêndio de Economia Regional: 515-533. Coimbra: Colecção APDR.

Miller, D. (1983), "The correlates of entrepreneurship in three types of firms", Management Science, 29(7): 770-791.

Mytelka, L. (1991), "Crisis, technological change and strategic alliance” In L. Mytelka (Ed.), Strategic Partnerships and the World Economy: 7-34, London, Pinter.

Newman, A. (2007), "Risk-bearing and entrepreneurship", Journal of Economic Theory, 137(1): 1-16.

OECD (2000), "Small and Medium-sized Enterprises: Local Strength, Global Reach", In O. Observer (Ed.), Policy Brief: Organisation for Economic Co-operation and Development.

OECD (2002), "OECD Small and Medium Enterprises Outlook”, In OECD (Ed.), OECD, Paris: Organization for Economic Co-operation and Development.

OECD, (2003), "The source of Economic Growth", In OECD (Ed.), OECD. Paris: Organization for Economic and Co-operation Development. 
Oliveira, C. B. (2005), "Os Desafios da Sustentabilidade", Revista Dirigir - Separata; Instituto do Emprego e Formação Profissional.

Olson, P. D. and Boker, D.W. (1995), "Strategy Process - content interaction: effects on growth performance in small start-up firms", Small Business Management, 33(1): 3444.

Palacio, J.R.S. (2006), "Local development and business creation. The role of local development workers in projecto management", Entrepreneurship Management, 2: 5778.

Pissarides, F. (1999), "Is lack of funds the main obstacle to growth? EBRD'S experience with small- and medium-sized businesses in Central and Eastern Europe", Journal of Business Venturing, 14: 519-539.

PNUD (2003), "Relatório do Desenvolvimento Humano de 2003", In PNUD (Ed.), Lisboa: Programa das Nações Unidas para o Desenvolvimento.

Porter, M. (1985), Competitive Advantage: Creating and sustaining superior performance, New York, Free Press.

Rajeswar, J. (2000), "Population perspectives and sustainable development", Sustainable Development, 8: 135-141.

Revell, A. and Blackburn, R. (2007), "The business case for sustainability? An examination of small firms in the UK's construction and restaurant sectors", Business Strategy and the Environment, 16: 404-420.

Rocha, M., Searcy, C. and Karapetrovic, S. (2007), "Integrating sustainable development into existing management systems", Total Quality Management \& Business Excellence, 18(1): 83-92.

Rosenfeld, S. A. (1996), "Does cooperation enhance competitiveness? Assessing the impacts of inter-firm collaboration", Research Polic y(25): 247-263.

Sarkar, M. B., Echambadi, R.A.J. and Harrison, J.S. (2001), "Alliance entrepreneurship and firm market performance", Strategic Management Journal, 22: 701-712.

Saunders, M., Lewis, P. and Thornhill, A. (2003), Research Methods for Business Students, Essex, Prentice Hall - Financial Times.

Schumpeter, J. (1934), The Theory of Economic Development, Cambridge.

Schwartz, R., Birch, N. and Teach, R. (2007), "Quantitative methodological considerations", In D. Hine \& D. Carson (Eds.), Innovative Methodologies in Enterprise Research: 54 64, Cheltenham, Edward Elgar.

Scott, M., Fadahunsi, A. and Kodithuwakku, S. (1997), "Tackling adversity with diversity", In S. Birley \& D. F. Muzyca (Eds.), Mastering enterprise: Your single-source to become an entrepreneur, London, Pitman.

Shanklin, W. and L.and Ryans, J.K. (1998), "Stoking the Small Business Engine", Business Horizons: 27 - 33.

Silva, E.G.D. and Pereira, V.B. (2007), "Economic activity and social class formation in the region of Vale do Sousa in Northwest Portugal", European Association for Evolutionary Political Economy, Porto, Portugal.

Stearns, T.M. and Hills, G. (1996), "Entrepreneurship and new firm development: A definitional introduction", Journal of Business Research, 34: 1-4.

Stel, A., Carree, M. and Thurik, R. (2005), "The effect of entrepreneurial activity on national economic growth", Small Business Economics, 24: 311-321.

Stevenson, H. n.d. "Why Entrepreneurship as Won!", Harvard University Graduate School of Business Administration. 
Stewart, H.W., Watson, E.W., Carland, J.C. and Carland, J.W. (1998), “A proclivity for entrepreneurship: A comparison of entrepreneurs, small business owners and corporate managers", Journal of Business Venturing(14): 189-214.

Stiglitz, J. E. and Driffill, J. (2000), Economics, New York, W.W. Norton.

Thornberry, N. (2001), "Corporate entrepreneurship: Antidote or Oximoron", European Management Journal, 19(5): 526-533.

UN. (1997), "Human Development Report", In U.N.D. Programme (Ed.), Oxford University Press, New Yorkm United Nations.

Vargas, C.M. (2000), "Community Development and Micro-enterprises: Fostering Sustainable Development", Sustainable Development, 8: 11-26.

Velho, A.V. (2003), "Os 4 Pilares das Empresas", Executive Digest: 48-53.

Venkataraman, S. (1997), The distinctive domain of entrepreneurship research. Advances in entrepreneurship, firm emergence and growth, Greenwich, Jai Press.

Voudouris, I., Lioukas, S., Makridakis, S. and Spanos, Y. (2000), "Greek Hidden Champions: Lessons from Small, Little-known Firms in Greece", European Management Journal, 18(6).

White, R., Thornhill, S. and Hampson, E. (2007), "A bisocial model of entrepreneurship: the combined effects of nurture and nature", Journal of Organizational Behaviour, 28: 451466.

Williams, P.M. (2002), "Community strategies: Mainstreaming sustainable development and strategic planning?", Sustainable Development, 10: 197-205.

Willums, J.-O. \& WBCSD. (2003), O Desafio da Empresa Sustentável - Orientações para os empresários do futuro ( $4^{\mathrm{a}}$ ed.), Porto, FirstMedia, Comunicação, S.A.

Wolfenshon, J. D. (1998), The other crisis, Washington DC, World Bank.

Wright, R.W. and Etemad, H. (2001), "SMEs and the global economy", Journal of International Management (7): 151-154.

Young, W. and Tilley, F. (2006), "Can business move beyond efficiency? The shift toward effectiveness and equity in the corporate sustainability debate", Business Strategy and the Environment, 15: 402-415.

Zampetakis, L. and Moustakis, V. (2006), "Linking creativity with entrepreneurial intentions: A structural approach", Entrepreneurship Management, 2: 413-428 